\title{
A kálium mútrágyázás hatása a kukorica hibridek bioetanol produkciójára
}

\author{
BOROS BEÁTA-SÁRVÁRI MIHÁLY \\ Debreceni Egyetem AGTC, Növénytudományi Intézet, Debrecen
}

\section{Összefoglalás}

Magyarországon évente 150 millió liter bioetanolt állítanak elô (a legjelentôsebb menynyiséget Szabadegyházán). A közeljövőben több nagykapacitású bioetanol üzem építését tervezik. Hazánkban lecsökkent az állatállomány, a kukorica felesleget nem tudjuk takarmányként felhasználni, a kukorica árak a nemzetközi piacon nyomottak. Ezek is indokolhatják a kukorica ipari felhasználásának növelését. A bioetanol előállítás hatékonyságának növelése érdekében ki kell választani - tesztelés útján - az erre a célra legalkalmasabb hibrideket, és a technológiát is a felhasználási célnak megfelelôen változtatni kell. Hiszen bioetanol elóállításnál fontos, hogy a keményítôtartalom nagyobb legyen (70-75\%). Mivel a N mútrágyák a fehérjetartalmat növelik, a K mútrágyák viszont a szénhidrát képződést segítik elő, ipari célú termesztés technológiánál a korábbi gyakorlathoz képest célszerúnek látszik a N kismértékú csökkenése és a K növelése az egyéb technológiai fegyelem betartása mellett.

A két kísérleti évben elért terméseredmények azt bizonyítják, hogy a kukoricából történô bioetanol előállításnál a keményítô tartalom mellett döntô vagy meghatározó tényező a hibridek termőképessége, az elért termés. Sớt a területegységrôl lehozható bioetanol szempontjából fontosabb a termőképesség, mint a keményító százalék.

Kulcsszavak: kukorica hibridek, bioetanol, mútrágyázás, tesztelés 


\title{
The effect of potassium fertilisation on the bioethanol production of maize hybrids
}

\author{
B. BOROS-M. SÁRVÁRI \\ University of Debrecen, Centre for Agricultural and Applied Economic Sciences, \\ Institute of Crop Sciences, Debrecen
}

\begin{abstract}
Summary
The yearly bioethanol production in Hungary is 150 million litre (with the highest amount being produced in Szabadegyháza). In the near future, several high capacity bioethanol plants are planned to be established. In Hungary, the amount of livestock has been reduced, we cannot use up the maize surplus as forage and the maize prices on the international market are low. These could also motivate the increased industrial utilisation of maize. In order to increase the efficiency of bioethanol production, we have to choose the most adequate hybrids - by means of testing - and the applied technology has to be changed in accordance with the aim of utilisation, as starch content needs to be higher in bioethanol production (70-75\%). Since $\mathrm{N}$ fertilisers increase protein content and $\mathrm{K}$ fertilisers improve carbohydrate production, it seems to be practical to slightly reduce $\mathrm{N}$ and increase $\mathrm{K}$ in industrial production technologies, while conforming to the technological discipline.

The yield results achieved in the two experimental years show that the yield potential and yield itself are also determinant factors in bioethanol production from maize besides starch content. Moreover, yield potential is more important than starch percentage from the aspect of the amount of bioethanol that can be produced on a unit area.
\end{abstract}

Key words: maize hybrids, bioethanol, fertilisation, testing 


\title{
Влияние калийного искусственного удобрения на продукцию биоэтанола кукурузных гибридов
}

\author{
Б. БОРОШ-М. ШАРВАРИ \\ Дебреценский Университет, Институт Растениеводства Центра \\ Агро-Экономических Наук, Дебрецен
}

\begin{abstract}
Резюме
В Венгрии ежегодно изготовляют 150 млн л биоэтанола (самое большое количество в Сабадедьхазе). В ближайшем будущем планируют строительство нескольких крупных заводов по производству биоэтанола. В Венгрии сократилось поголовье домашних животных, излишек кукурузы не можем применять для их корма, цена кукурузы на мировом рынке низкая. Всё это может мотивировать рост использования кукурузы в промышленности. В интересах увеличения эффективности производства биоэтанола надо выбрать - тестированием - самые подходящие для этой цели гибриды, а также надо изменить и технологию в соответствии с целью использования. Ведь при производстве биоэтанола важно, чтобы содержание крахмала было больше (70-75\%). Поскольку N удобрения увеличивают содержание белка, а К удобрения способствуют формированию углеводов, в технологиях для промышленных целей по сравнению с имеющимся опытом целесообразным выглядит небольшое уменьшение $\mathrm{N}$ и увеличение К при сохранении прочих технологических норм.

Полученные результы урожаев за два года опытов доказывают, что при производстве биоэтанола из кукурузы вместе с содержанием крахмала важным или решающим фактором является плодородие гибридов, полученный урожай. Даже с точки зрения полученного с единицы территории биоэтанола более важна плодородность, чем процент крахмала.
\end{abstract}

Ключевые слова: гибриды кукурузы, биоэтанол, искусственные удобрения, тестирование 


\section{Bevezetés}

Magyarország 1,2 millió hektáron reálisan 8-9 millió tonna kukoricát tud megtermelni évente. A növénytermesztés-állattenyésztés kedvezőtlen 70:30 aránya következtében jelentős kukorica feleslegeink vannak, melyeket gazdaságosabb lehet itthon ipari célra felhasználni, mint a külpiacokon értékesíteni. A magyarországi bioetanol ipar felfuttatása megoldaná a kukoricatermelôk értékesítési gondjait, stabilizálná az agrárium helyzetét. Popp és Potori (2006) szerint a bioetanol-ipar új és erôteljesen bôvülô felvevôpiac lesz a gabonafélék számára, ami kétségtelenül kedvező a gabonatermelőknek.

Az Európai Unió a tagállamokra nézve kötelezó határozatot hozott a bioüzemanyagok motorhajtóanyagokon belüli részarányának 2020-ig 10\%-ra történô növelésére. Azok az országok, melyek a megfelelő mennyiségú etanolt nem tudják saját maguk előállítani, viszont az etanol üzemanyagban történô részarányának növelése számukra is kötelező, importra szorulnak. Ezért a Magyarországon előállítható etanolnak, és így az ehhez szükséges kukoricának is biztos piaca lesz hosszú távon. A kukoricából történô etanol előállítás gazdaságosan valósul meg számos országban (1. ábra).

Bioetanol számos növénybôl előállítható: ôszi búza, kukorica, cukorrépa, cukornád, cukorcirok, burgonya, csicsóka. A felsorolt növények közül Magyarországon - a jelenlegi termelési körülmények között - kukoricából lehet a leghatékonyabban etanolt előállítani.

A bioetanol célú felhasználásra a magas keményítôtartalmú hibridek kedvezóek, ezért nagyon fontos a termesztési célnak megfelelő hibridválasztás. Az irodalmi adatok szerint a kukorica szárazanyagra számított keményítőtartalma 65-70\%, azonban napjainkban vannak már olyan kukorica hibridek is, amelyek szemtermésének keményítőtartalma eléri a 75\%-ot. Ezeket a nemesítőházak HTF (High Total Fermentable) jelöléssel különböztetik meg a takarmányozási célra kedvezőbb beltartalommal rendelkezó hibridektôl (magasabb fehérjetartalmúak).

Bár a minôségi paraméterek örökletesen meghatározottak (elsôsorban a fehérje és olajtartalom), az ökológiai és agrotechnikai tényezők azt módosíthatják (Gundel et al. 1981, Kissné 1982, Pásztor és Kováts 1985, Nagy 1997, Izsáki 2006).

A biotenol előállítás hatékonyságát növelhetjük a termesztési célnak megfelelő technológiával, melyeknek legfontosabb elemei: a hibridválasztás, az 
NPK tápanyagellátáson belül az N-P-K táparány változtatása, az optimum intervallumon belüli tőszámnövelése stb.

1. ábra. Európa jelentôsebb bioetanol elóállító országai által termelt bioetanol mennyisége (2004-2008)

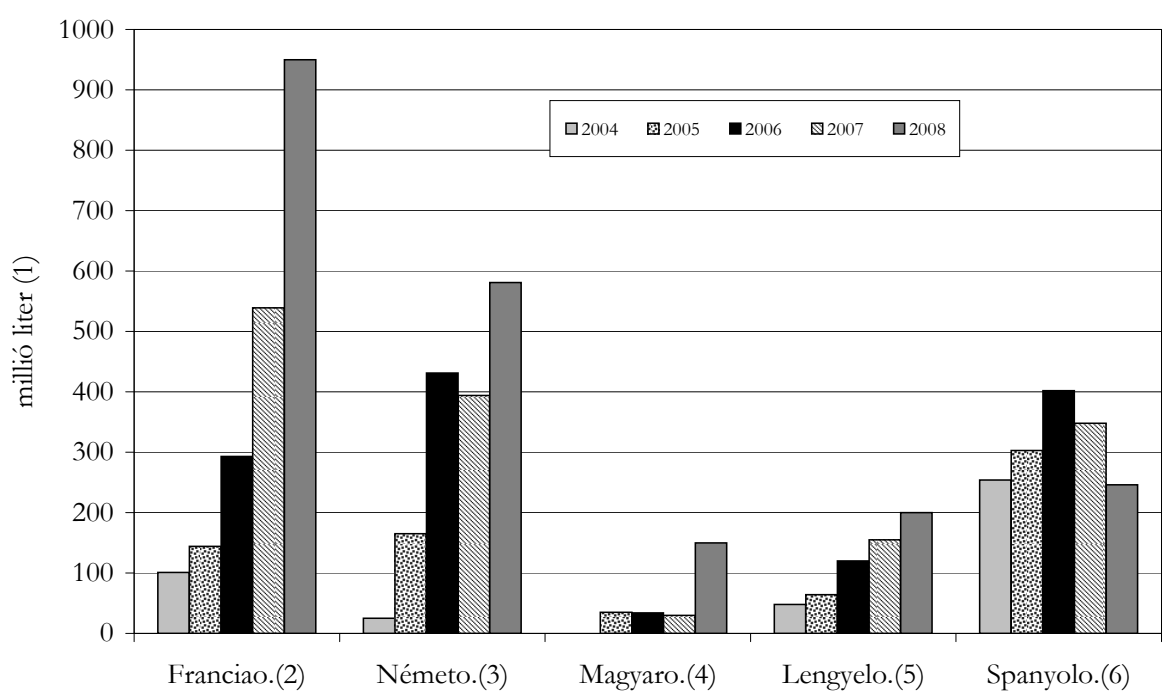

Figure 1. The quantity of bioethanol produced by the major bioethanol producing countries in Europe (2004-2008). (1) Million litre, (2) France, (3) Germany, (4) Hungary, (5) Poland, (6) Spain.

A N-trágyázás a kukorica fehérjetartalmát növeli, de mennyiségét alapvetôen a fajta (hibrid) genotípusa határozza meg. Győrffy et al. (1965) szerint a N-mútrágyázás növeli a kukorica fehérjetartalmát, de nem javítja a fehérje minôségét, mert hatására a kevésbé értékes aminosavak aránya nő. Az esszenciális aminosavak növekedési üteme elmarad a nem esszenciális aminosavak növekedésétől (Pekáry 1969, Breteler 1976, Decan és Pujol 1974, Veress 1973).

A kukoricahibridek fehérjetartalma a növekvô nitrogén szintek hatására csak egy bizonyos érték eléréséig nô, majd a növekedés üteme fokozatosan mérséklődik. A trágyázatlan körülményekhez viszonyítva a növekvő nitrogén mútrágyaadag hatására nagyobb arányú a termésnövekedés és kisebb a fehérjenövekedés (Prokszáné et al. 1995). Berzsenyi és Varga (1986) is ezt a megállapítást teszi, miszerint a nitrogén mútrágyázásra a kukorica elsôdlegesen a termés növekedésével válaszol, és másodlagosan a fehérjetartalom növekedésével. 
Míg a fehérjetartalmat a N-mútrágya, addig az olaj- és keményítótartalmat a P, K-mútrágyák növelik (Getmanec és Kaljavzo 1981). Ezért bioetanol célú termesztés esetén célszerú lehet a $\mathrm{N}$ mútrágya kismértékú növelése, amely a szénhidrát képzést segíti elő (Sárvári és Boros 2009.).

A kukorica termését meghatározó tényezők közül a növényszám 20\%-kal részesül (Gyơrffy 1976). Nagyobb állománysûrúségben a mútrágyahatás is nô, ezért fontos a termesztési színvonalhoz és a termesztés céljához igazodó tôszám megválasztása (Nagy 1995).

A szem beltartalmi értékének változását vizsgálta Prokszáné és Harmati (1988). Eredményei alapján azt találta, hogy a területegységre vetített tőszám növelése esetén a keményítô tartalom növekedett, míg a fehérje, illetve az olajtartalom csökkent. Ennek az a magyarázata, hogy a tôszám növelésére, mint stresszhelyzetre a növény a nagyobb energiaigényú fehérje- olajszintézis folyamatok csökkentésével reagál.

A tôszám optimum intervallumon belül a felsô értékhez közelítve, valamint az optimálisnál némileg nagyobb tôszám a fehérje és olajtartalmat csökkenti, keményítôtartalmat pedig növeli (Sárvári és Szabó 1998).

\section{Anyag és módszer}

\section{A kísérlet talajának jellemzése}

A kísérletet mindkét évben a hajdúsági löszháton elhelyezkedő csernozjom talajon végeztük.

A talaj Arany-féle kötöttségi száma 43, szervesanyag tartalma 2,92\%, $\mathrm{NO}_{3}-\mathrm{N}$ mennyiség 33,6 mg/kg, $\mathrm{P}_{2} \mathrm{O}_{5}$ tartalma $313,6 \mathrm{mg} / \mathrm{kg}$, a $\mathrm{K}_{2} \mathrm{O}$ tartalma 354,8 $\mathrm{mg} / \mathrm{kg}$. Az AL oldható PK tartalom alapján a talaj $\mathrm{P}$ és $\mathrm{K}$ tartalma a vizsgálati eredmények szerint igen jó.

A talaj jó víz- levegô- és hôgazdálkodású. Erre a talajtípusra jellemző a humuszanyagok felhalmozódása, a kedvezó, morzsalékos szerkezet, valamint a kalciummal telített talajoldat kétirányú mozgása.

A szerves anyag szelvényen belüli eloszlását befolyásolja a talajlakó állatok tevékenysége. A termőréteg viszonylag mély és sok szerves anyagot tartalmazó morzsalékos szerkezetú, jó víz és tápanyag-gazdálkodású, a humuszos szint fokozatos átmenetet mutat. Az „A” szint kb. 90 cm, és csak árnyalati különbséggel megy át a „B” szintbe. 
A talaj vízgazdálkodása igen jó, mert minden szintjének kiváló a vízáteresztése és víztároló képessége. Amennyiben $200 \mathrm{~cm}$ mélységig fel tud töltôdni, akkor $500 \mathrm{~mm}$ vizet is képes tárolni, melynek fele holt, fele pedig diszponibilis - a növények számára is felvehető - víztartalom.

\section{Időjárási feltételek}

Az általunk vizsgált 2 év (2007 és 2008) időjárása rendkívül eltérô volt.

\section{7. évi időjárás értékelése}

A 2007-es év száraz, aszályos volt. A legnagyobb csapadékhiány áprilisban, júniusban és júliusban mutatkozott, áprilisban 38,6 mm-rel, júniusban 64,1 mm-rel, július hónapban 22,7 mm-rel hullott kevesebb csapadék a 30 éves átlaghoz viszonyítva.

A kukorica tenyészidejében 53,9 mm-rel kevesebb csapadék hullott a sokévi átlaghoz viszonyítva, emellett még a kedvezótlen eloszlása is hátráltatta a megtermékenyülést és a szemtelítôdést (2. ábra).

\section{2. ábra. A hömérséklet és csapadék viszonyok alakulása}

(Hajdúböszörmény 2007)

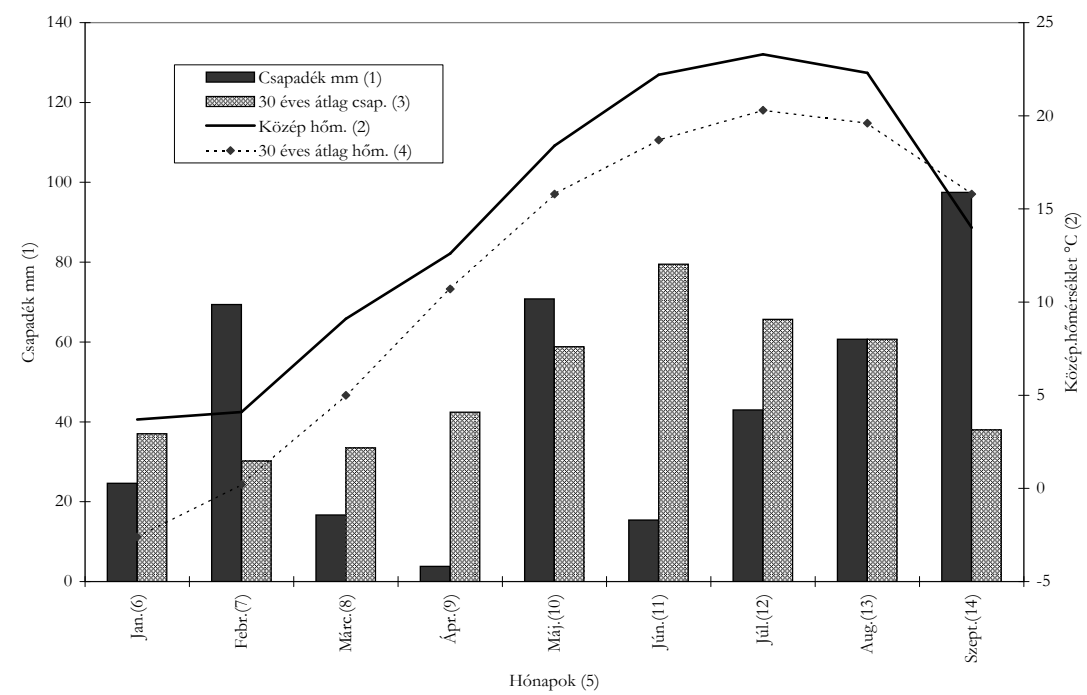

Figure 2. Temperature and rainfall (Hajdúböszörmény 2007). (1) Rainfall (mm), (2) Mean temperature ${ }^{\circ} \mathrm{C}$, (3) 30-year average rainfall, (4) 30-year average temperature, (5) Months, (6) January, (7) February, (8) March, (9) April, (10) May, (11) June, (12) July, (13) August, (14) September. 
A havi középhőmérséklet az I-VIII. hónapokban lényegesen magasabb volt a 30 éves átlaghoz viszonyítva, szeptember hónapban viszont alacsonyabb.

Januárban $6,3^{\circ} \mathrm{C}-\mathrm{kal}$, februárban 3,9 ${ }^{\circ} \mathrm{C}-\mathrm{kal}$, márciusban $4,1^{\circ} \mathrm{C}-\mathrm{kal}$, áprilisban $1,9^{\circ} \mathrm{C}-\mathrm{kal}$, májusban $2,5^{\circ} \mathrm{C}$-kal, júniusban $3,5^{\circ} \mathrm{C}-\mathrm{kal}$, júliusban $3,0^{\circ} \mathrm{C}-\mathrm{kal}$, augusztusban $2,7^{\circ} \mathrm{C}-\mathrm{kal}$ volt magasabb a hômérséklet a sokévi átlaghoz viszonyítva. A kukorica szempontjából különösen kedvezótlen volt a júliusi magas hômérséklet. Szeptember hónapban a havi középhőmérséklet 1,8 C-kal alacsonyabb volt a 30 éves átlaghoz viszonyítva.

A kukorica tenyészidejében (IV-IX. hó) a hômérséklet 30 éves átlaga $16,32^{\circ} \mathrm{C}$, a 2007 . évi havi középhômérséklet átlaga (IV-IX. hó) $18,78{ }^{\circ} \mathrm{C}$ volt, vagyis a kukorica tenyészidejében $1,96^{\circ} \mathrm{C}-\mathrm{kal}$ magasabb volt a havi középhômérséklet átlaga a 30 éves átlaghoz viszonyítva.

\section{8. évi időjárás értékelése}

A 2007-es évvel ellentétben 2008. év időjárása kedvező volt a kukorica számára. A kukorica tenyészidejében (IV-IX. hó.) a 30 éves csapadékátlag 345,1 mm, ehhez viszonyítva 2008-ban a tenyészidőben 77,3 mm-rel több csapadék hullott. Különösen csapadékos volt április, június és július hónap. Augusztus hónapban - országosan - a sokévi csapadéknak csupán egyharmada hullott, azonban Hajdúböszörményben csak 12,8 mm-rel kevesebb a 30 éves átlaghoz képest. A kukorica termékenyülése és a kezdeti szemtelítôdése szempontjából különösen kedvezô volt, hogy az átlaghômérséklet a sokévi átlag körül alakult, a ténylegesen lehullott csapadék júliusban 125,9 mm volt, ez az érték 60,2 mm-rel volt több, mint a 30 éves átlag (3. ábra).

Összességében elmondhatjuk, hogy Hajdúböszörmény időjárása rendkívül kedvezően alakult a kísérleti években. A havi középhőmérsékleti értékek minden hónapban kismértékben meghaladták a 30 éves átlagot, ami megfeleló vízellátással is párosult. Ennek a következménye, hogy nagyon jó terméseredményeket értek el a fajták, még a korai érésú hibridek is.

\section{Kisérleti körülmények és az alkalmazott agrotechnika}

A kísérlet helye: Hajdúböszörmény, I-es kerület. Hajdúsági löszháton csernozjom talaj. A kísérleteket négy ismétlésben, véletlen blokk elrendezésben állítottuk be. 
3. ábra. A hőmérséklet és csapadék viszonyok alakulása

(Hajdúböszörmény 2008)

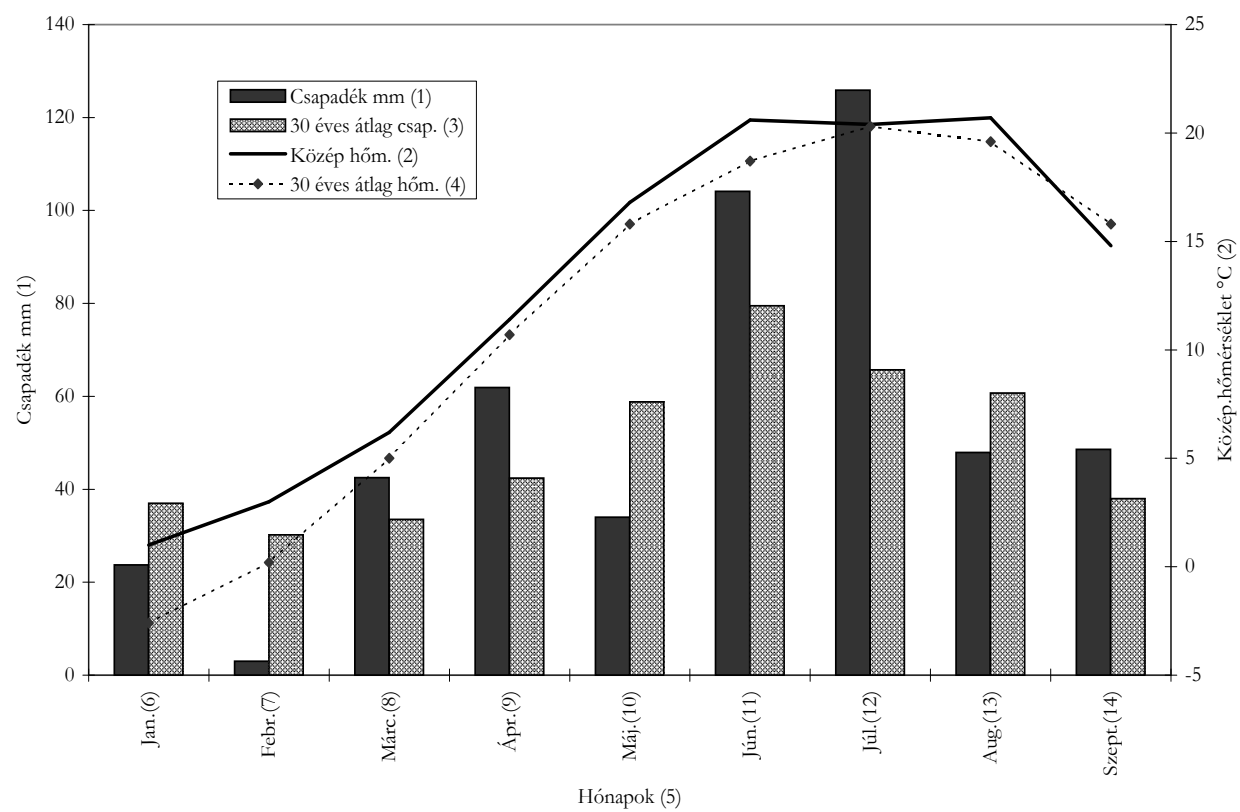

Figure 3. Temperature and rainfall (Hajdúböszörmény 2008). (1) Rainfall (mm), (2) Mean temperature ${ }^{\circ} \mathrm{C}$, (3) 30-year average rainfall, (4) 30-year average temperature, (5) Months, (6) January, (7) February, (8) March, (9) April, (10) May, (11) June, (12) July, (13) August, (14) September.

Parcella mérete: $\quad$ Bruttó: 3,04 $\mathrm{m} \times 5 \mathrm{~m}=15,2 \mathrm{~m}^{2}$

Nettó: $3,04 \mathrm{~m} \times 4 \mathrm{~m}=12,6 \mathrm{~m}^{2}$

Tôszám: $\quad 1-3$. hibrid: 73 ezer tô/ha, 4-5. hibrid: 69 ezer tô/ha

\section{Tápanyagellátás}

Azonos $\mathrm{N} 120, \mathrm{P}_{2} \mathrm{O}_{5} 80 \mathrm{~kg} /$ ha-os mútrágyakezelés mellett, a kálium formáját és adagját változtatva.

1. kezelés: (kontroll) K mûtrágya nélkül

2. kezelés: $100 \mathrm{~kg} / \mathrm{ha} \mathrm{KCl},(60 \%-o s)$

3. kezelés: 100 kg/ha Kornkáli (40\%-os)

4. kezelés: $200 \mathrm{~kg} / \mathrm{ha} \mathrm{KCl}$

5. kezelés: 200 kg/ha Kornkáli mútrágya 
A kísérletben beállitott hibridek

1. PR38B12 (FAO 310)

2. PR37D25 (FAO 330)

3. KWS 353 (FAO 350)

4. DKC 5211 (FAO 460)

5. PR36K67 (FAO 490)

A bioetanol hozam meghatározásánál több tényezót vettünk figyelembe, beltartalmi paraméterek közül a szem keményítôtartalmát, a hektáronkénti terméshozam mellett a hektáronkénti keményítôhozamot és a kierjeszthetố tiszta víztelenített alkohol tartalmat, mely alapvetôen a nedves kiôrlésnél képzôdött $\mathrm{CO}_{2}$ koncentráció alapján lett kiszámolva.

\section{Eredmények és értékelése}

Öt eltérố genetikai tulajdonságú kukoricahibridet teszteltünk, azonos N 120, $\mathrm{P}_{2} \mathrm{O}_{5} 80 \mathrm{~kg} / \mathrm{ha}$-os mútrágyakezelés mellett, a kálium formáját és adagját változtatva.

A kísérlet hajdúsági löszháton - csernozjom talajon lett beállítva. Az idójárás 2007-ben szélsôséges volt. Különösen kedvezôtlenül érintette a kukorica növényeket a megtermékenyülés és szemtelítôdés kezdeti idôszakában a $3{ }^{\circ} \mathrm{C}$ kal magasabb július havi középhőmérséklet.

A tesztelt hibridkukorica fajták ennek ellenére jól szerepeltek, kiemelkedó terméseredményeket értek el, aminek egyik magyarázata lehet, hogy a kísérlet kiváló talajon lett beállítva (1. táblázat). A talajban volt elegendố hasznos vízkészlet, míg monokultúrás termesztésnél már tavasszal a talajok a holtvíztartalomig ki voltak száradva, mivel az elôző ősz és a 2007. év eleje száraz és aszályos volt.

Mérési eredményeink szerint a PR37D25 és PR36K67 hibrid termése a többi vizsgált hibridhez viszonyítva szignifikánsan nagyobb, a DKC 5211 termése pedig szignifikánsan kisebb volt. A mútrágyakezelés és a termés közötti összefüggést értékelve látható, hogy a hibridek átlagában már a K mútrágyázás nélküli kezelésnél is 10,39 t/ha a termés, ehhez viszonyítva a $100 \mathrm{~kg}$ Kornkáli kezelés (egy esetben a KCl kezelés a PR37D25 hibridnél) 0,68-1,92 t/ha-ral növelte a területegységre vetített termést (4. ábra). 
1. táblázat. A hibridek rangsorolása a mütrágyakezelés és a termés alapján (Hajdúböszörmény 2007)

\begin{tabular}{|c|c|c|c|c|c|}
\hline \multirow{2}{*}{$\begin{array}{l}\text { A hibrid neve } \\
\text { (1) } \\
\text { 1. PR36K67 }\end{array}$} & \multirow{2}{*}{$\begin{array}{c}\text { FAO } \\
\text { szám } \\
(2) \\
490\end{array}$} & \multirow{2}{*}{$\begin{array}{c}\text { Termés- } \\
\text { maximum } \\
\text { t/ha } \\
(3) \\
14,62\end{array}$} & \multicolumn{3}{|c|}{$\begin{array}{c}\text { Termésmaximumhoz tartozó } \\
\text { mútrágyakezelés } \\
\mathrm{kg} / \mathrm{ha} \text { hatóanyag } \\
(4)\end{array}$} \\
\hline & & & N 120 & $\mathrm{P}_{2} \mathrm{O}_{5} 80$ & Kornkáli 100 \\
\hline 2. PR37D25 & 330 & 13,25 & N 120 & $\mathrm{P}_{2} \mathrm{O}_{5} 80$ & KCl 100 \\
\hline 3. KWS 353 & 350 & 11,65 & N 120 & $\mathrm{P}_{2} \mathrm{O}_{5} 80$ & Kornkáli 100 \\
\hline 4. PR38B12 & 310 & 11,63 & N 120 & $\mathrm{P}_{2} \mathrm{O}_{5} 80$ & Kornkáli 200 \\
\hline 5. DKC 5211 & 460 & 10,53 & N 120 & $\mathrm{P}_{2} \mathrm{O}_{5} 80$ & Kornkáli 200 \\
\hline Átlag (5) & & 12,34 & & & \\
\hline
\end{tabular}

Table 1. Classification of hybrids based on fertilisation treatments and yield (Hajdúböszörmény 2007). (1) Hybrid name, (2) FAO number, (3) Maximum yield t ha-1, (4) Fertilisation treatment of the given yield maximum, $\mathrm{kg}$ active ingredient ha-1, (5) Average.

4. ábra. A mütrágyázás hatása a kukoricahibridek termésére

(Hajdúböszörmény 2007)

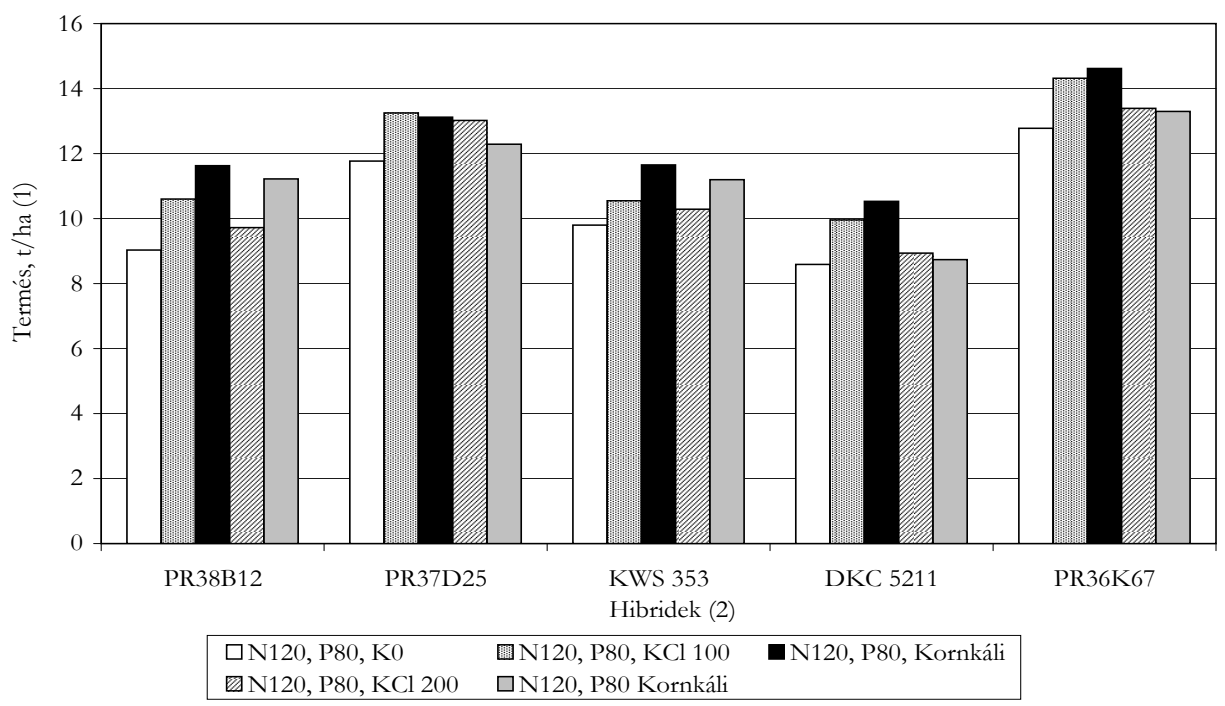

$\mathrm{SzD}_{5 \%}$ hibrid = 0,63 t/ha, $\mathrm{SzD}_{5 \%}$ mútrágyázás = 0,59 t/ha, $\mathrm{SzD}_{5 \%}$ kölcsönhatás = 1,32 t/ha.

Figure 4. The effect of fertilisation on the yield of maize hybrids (Hajdúböszörmény 2007). (1) Yield tha ${ }^{-1},(2)$ Hybrids. $\mathrm{LSD}_{5 \%}$ hybrid $=0.63 \mathrm{tha}^{-1}, \mathrm{LSD}_{5 \%}$ fertilisation $=0.59 \mathrm{t} \mathrm{ha}^{-1}, \mathrm{LSD}_{5 \%}$ interaction $=1.32 \mathrm{tha}^{-1}$. 
Kísérleteinkben a szemtermések fehérjetartalma hibridektől és az NPK trágyakezeléstől függôen 10,28-12,13\% között változott, ami igen magas fehérjetartalomnak számít. Egyértelmúen megállapítható, hogy az intervallumon belül is általában az N 120, $\mathrm{P}_{2} \mathrm{O}_{5} 80, \mathrm{~K}_{2} \mathrm{O} 200(\mathrm{KCl}) \mathrm{kg} /$ ha hatóanyag kezelésnél volt legmagasabb a fehérje százalék. A fajták tekintetében pedig a KWS 353 hibrid fehérje százaléka volt a legnagyobb, 11,71-12,35\% közötti. Az alacsonyabb 11,71\%-os fehérjetartalmat a kontroll (K kezelés nélküli) kezelésnél kaptuk (2. táblázat).

A legkisebb fehérje százalékot - a kezelések átlagában - a PR36K67 hibridnél mértük, 10,28\%-ot. Az olaj százalék hibridtől és kezeléstől függôen 4,87-5,19\% között változott.

A hibridek szemtermésének keményítőtartalma is kedvezóen alakult a vizsgált évben. A vizsgált öt hibridnél kezeléstől függően 71,79-73,5\% között változott.

A legnagyobb keményítőtartalmat a PR37D25 hibrid mintáiban mértük, 73,59\%-ot, a legkedvezőbb keményítő százalékot pedig (73,82\%) az N 120, $\mathrm{P}_{2} \mathrm{O}_{5} 80, \mathrm{~K}_{2} \mathrm{O} 200$ (Kamex) kg/ha hatóanyag kezelésnél. A hibrid maximális termése 13,25 t/ha volt, ami kiemelkedóen jó eredménynek számít.

A KWS 353 hibridnél a keményítő százalék a kezelések átlagában csak 71,79\% volt, ugyanakkor már említettük, hogy a fehérje százaléka a legmagasabb volt 12,13\%. Ezek alapján a hibrid bioetanol előállításra nem a legkedvezóbb tulajdonságokkal rendelkezik.

A kálium egyértelmúen nem növelte a kukoricaszem keményítő százalékát, hiszen elôfordult, hogy kálium mútrágyázás nélkül is kedvezôen alakult pl. KWS-353 és PR36K67 hibrideknél. Ez természetesen a kedvezô termőhelyi adottságnak, a talaj jó kultúrállapotának, az igen jó $\mathrm{AL}$ oltható $\mathrm{K}_{2} \mathrm{O}$ ellátottságának (354,8 mg/kg), továbbá a jó tápanyag szolgáltató képességének is köszönhető.

A 3. táblázatban bemutatott eredményekkel csak tendenciájában és elméletileg mutattunk rá a vizsgált kukorica hibridekből elóállítható bioetanol mennyiségére, hiszen a termésmennyiség és a keményítőtartalom mellett a fermentálhatóság is fontos, amit 2008. évtől vizsgáltunk. 
2. táblázat. A kálium mütrágyázás hatása a kukoricahibridek minôségére (Hajdúböszörmény 2007)

\begin{tabular}{|c|c|c|c|c|c|}
\hline $\begin{array}{l}\text { Hibrid } \\
\text { (1) }\end{array}$ & $\begin{array}{c}\text { Mútrágya-kezelés } \\
\text { (2) }\end{array}$ & $\begin{array}{c}\text { Fehérje } \\
\% \\
\text { (3) }\end{array}$ & $\begin{array}{c}\text { Keményítő } \\
\% \\
\text { (4) }\end{array}$ & $\begin{array}{c}\text { Olaj } \\
\% \\
(5)\end{array}$ & $\begin{array}{c}\text { Szárazanyag } \\
\% \\
\text { (6) }\end{array}$ \\
\hline \multirow{3}{*}{$\begin{array}{l}\text { PR38 } \\
\text { B12 }\end{array}$} & N120 P80 K0 & 11,65 & 72,19 & 4,93 & 91,34 \\
\hline & N120 P80 KCl 200 & 12,34 & 72,70 & 5,04 & 91,71 \\
\hline & N120 P80 Kamex 200 & 11,78 & 72,51 & 5,15 & 91,82 \\
\hline \multicolumn{2}{|l|}{ Átlag (7) } & 11,92 & 72,47 & 5,04 & 91,62 \\
\hline \multirow{3}{*}{$\begin{array}{l}\text { PR37 } \\
\text { D25 }\end{array}$} & N120 P80 K0 & 10,72 & 73,15 & 4,99 & 91,51 \\
\hline & N120 P80 KCl 200 & 10,92 & 73,81 & 4,80 & 91,51 \\
\hline & N120 P80 Kamex 200 & 10,64 & 73,82 & 4,83 & 91,60 \\
\hline \multicolumn{2}{|l|}{ Átlag (7) } & 10,76 & 73,59 & 4,87 & 91,54 \\
\hline \multirow{3}{*}{$\begin{array}{l}\text { KWS } \\
353\end{array}$} & N120 P80 K0 & 11,71 & 72,33 & 5,22 & 91,70 \\
\hline & N120 P80 KCl 200 & 12,35 & 71,74 & 5,25 & 91,28 \\
\hline & N120 P80 Kamex 200 & 12,33 & 71,31 & 5,10 & 91,51 \\
\hline \multicolumn{2}{|l|}{ Átlag (7) } & 12,13 & 71,79 & 5,19 & 91,50 \\
\hline \multirow{3}{*}{$\begin{array}{l}\text { DKC } \\
211\end{array}$} & N120 P80 K0 & 11,36 & 72,75 & 5,12 & 91,51 \\
\hline & N120 P80 KCl 200 & 11,31 & 72,30 & 5,02 & 91,40 \\
\hline & N120 P80 Kamex 200 & 11,21 & 72,85 & 4,94 & 91,01 \\
\hline \multicolumn{2}{|l|}{ Átlag (7) } & 11,29 & 72,63 & 5,03 & 91,30 \\
\hline \multirow{3}{*}{$\begin{array}{l}\text { PR36 } \\
\text { K67 }\end{array}$} & N120 P80 K0 & 9,86 & 74,04 & 4,86 & 91,49 \\
\hline & N120 P80 KCl 200 & 10,65 & 73,49 & 4,89 & 91,42 \\
\hline & N120 P80 Kamex 200 & 10,33 & 73,20 & 4,89 & 91,72 \\
\hline \multicolumn{2}{|l|}{ Átlag (7) } & 10,28 & 73,57 & 4,88 & 91,54 \\
\hline
\end{tabular}

Table 2. The effect of potassium fertilisation on the quality of maize hybrids (Hajdúböszörmény 2007). (1) Hybrid, (2) Fertiliser treatment, (3) Protein \%, (4) Starch \%, (5) Oil \%, (6) Dry matter \%, (7) Average.

A 2008.-as évben ugyanazon hibrideket termesztettünk, azonos NPK mútrágyakezelés mellett. Ennek az évnek az idôjárása igen kedvezô volt a kukoricatermesztés számára. A vizsgált hibridek közül a legnagyobb terméseredményeket a PR37D25 és PR36K67 hibridek érték el. Viszonylag jól szerepelt még a PR38B12 hibrid. A KWS 353 és DKC 5211 hibridek szerényebb terméseredményeket értek el (5. ábra) 
3. táblázat. A hibridek maximális termése és keményitő hozama (Hajdúböszörmény 2007)

\begin{tabular}{cccccc}
\hline $\begin{array}{c}\text { Hibrid neve } \\
(1)\end{array}$ & $\begin{array}{c}\text { FAO } \\
\text { szám } \\
(2)\end{array}$ & $\begin{array}{c}\text { Maximális } \\
\text { termés t/ha } \\
(3)\end{array}$ & $\begin{array}{c}\text { Szárazanyag \%-a } \\
\text { kezelések } \\
\text { átlagában } \\
(4)\end{array}$ & $\begin{array}{c}\text { Termés } \\
\text { szárazanyag } \\
\text { átszámítva } \\
(5)\end{array}$ & $\begin{array}{c}\text { Keményítő } \\
\text { t/ha } \\
(6)\end{array}$ \\
\hline PR38B12 & 310 & 11,63 & 91,62 & 10,66 & 7,73 \\
PR37D25 & 330 & 13,25 & 91,54 & 12,13 & 8,93 \\
KWS353 & 350 & 11,65 & 91,50 & 10,66 & 7,65 \\
DKC5211 & 460 & 10,53 & 91,30 & 9,61 & 6,98 \\
PR36K67 & 490 & 14,62 & 91,54 & 13,38 & 9,84 \\
\hline
\end{tabular}

(1 tonna kukoricából az irodalmi adatok szerint 387 liter bioetanol nyerhetô)

Table 3. The maximum yield and starch production of hybrids (Hajdúböszörmény 2007). (1) Hybrid name, (2) FAO number, (3) Maximum yield, $\mathrm{t} \mathrm{ha}^{-1}$, (4) Dry matter \% in the average of treatments, (5) Converted value of yield dry matter, (6) Starch t ha ${ }^{-1}$. (Based on bibliographic data, 387 litre bioethanol can be extracted from $1 \mathrm{t}$ maize)

\section{5. ábra. A mútrágyázás hatása a kukoricahibridek termésére}

(Hajdúböszörmény 2008)



$\mathrm{SzD}_{5 \%}$ hibrid = 0,63 t/ha, $\mathrm{SzD}_{5 \%}$ mútrágyázás = 0,29 t/ha, $\mathrm{SzD}_{5 \%}$ kölcsönhatás = 0,64 t/ha.

Figure 5. The effect of fertilisation on the yield of maize hybrids (Hajdúböszörmény 2008).

(1) Yield t ha ${ }^{-1}$, (2) Hybrids. $\mathrm{LSD}_{5 \%}$ hybrid $=0.63 \mathrm{tha}^{-1}, \mathrm{LSD}_{5 \%}$ fertilisation $=0.29 \mathrm{t} \mathrm{ha}^{-1}, \mathrm{LSD}_{5 \%}$ interaction $=0.64 \mathrm{tha}^{-1}$. 
A 2008-as tenyészévben a havi középhômérséklet minden hónapban kismértékben meghaladta a 30 éves átlagot, ami megfelelő vízellátással is párosult, ennek következtében kiemelkedő terméseredményeket értek el a hibridek, még a korai érésúek is. A vizsgált hibridek termése 9-17 t/ha között változott. Kiemelkedô hozam jellemezte a PR36K67 (FAO 490) hibridet, melynek termésmaximuma 17,15 t/ha volt. Ezt a kiváló terméseredményt az $\mathrm{N}$ $120, \mathrm{P}_{2} \mathrm{O}_{5} 80, \mathrm{~K}_{2} \mathrm{O} 200(\mathrm{KCl}) \mathrm{kg} /$ ha hatóanyag kezelésnél érte el. A vizsgált hibridek közül három: a PR37D25, a PR38B12 és a DKC 5211 hibridek maximális termésüket $100 \mathrm{~kg} /$ ha Kornkáli kezelés mellett produkálták (4. táblázat).

A 2008. évi kiemelkedố terméseredmények elsôsorban a kedvezó évjáratnak és a hibridek genetikailag determinált jó termőképességének volt köszönhetô.

4. táblázat. A hibridek rangsorolása a mütrágyakezelés és a termés alapján (Hajdúböszörmény 2008)

\begin{tabular}{|c|c|c|c|c|c|}
\hline \multirow{2}{*}{$\begin{array}{l}\text { A hibrid neve } \\
\text { (1) } \\
\text { 1. PR36K67 }\end{array}$} & \multirow{2}{*}{$\begin{array}{c}\text { FAO } \\
\text { szám } \\
(2) \\
490\end{array}$} & \multirow{2}{*}{$\begin{array}{c}\text { Termés- } \\
\text { maximum } \\
\text { t/ha } \\
(3) \\
17,15\end{array}$} & \multicolumn{3}{|c|}{$\begin{array}{c}\text { Termésmaximumhoz tartozó } \\
\text { mútrágyakezelés } \\
\mathrm{kg} / \text { ha hatóanyag } \\
(4)\end{array}$} \\
\hline & & & N 120 & $\mathrm{P}_{2} \mathrm{O}_{5} 80$ & KCl 200 \\
\hline 2. PR37D25 & 330 & 15,12 & N 120 & $\mathrm{P}_{2} \mathrm{O}_{5} 80$ & Kornkáli 100 \\
\hline 3. PR38B12 & 310 & 14,02 & N 120 & $\mathrm{P}_{2} \mathrm{O}_{5} 80$ & Kornkáli 100 \\
\hline 4. DKC 5211 & 460 & 11,37 & N 120 & $\mathrm{P}_{2} \mathrm{O}_{5} 80$ & Kornkáli 100 \\
\hline 5. KWS 353 & 350 & 10,82 & N 120 & $\mathrm{P}_{2} \mathrm{O}_{5} 80$ & $\mathrm{KCl} 200$ \\
\hline Átlag (5) & & 13,70 & & & \\
\hline
\end{tabular}

Table 4. Classification of hybrids based on fertilisation treatments and yield (Hajdúböszörmény 2008). (1) Hybrid name, (2) FAO number, (3) Maximum yield $\mathrm{t} \mathrm{ha}^{-1}$, (4) Fertilisation treatment of the given yield maximum, $\mathrm{kg}$ active ingredient $\mathrm{ha}^{-1},(5)$ Average.

A kukoricahibridek beltartalmi paraméterei az 5. táblázatban láthatók. A keményítőtartalom 65,30-72,04\% között alakult. A legnagyobb keményítótartalmakat a PR36K67 és a PR38B12 hibridek érték el, N 120, $\mathrm{P}_{2} \mathrm{O}_{5} 80, \mathrm{KCl}$ 200 kezelés mellett. Kedvezóen alakult a PR37D25 hibrid keményítő \%-a is (68,95-70,57\%), az előzó évihez hasonlóan, a legkedvezőbb keményítô százalékot az N 120, $\mathrm{P}_{2} \mathrm{O}_{5} 80, \mathrm{~K}_{2} \mathrm{O} 200$ (Kamex) kg/ha hatóanyag kezelésnél érte el. 
5. táblázat. A kálium mütrágyázás hatása a kukoricahibridek minôségére (Hajdúböszörmény 2008)

\begin{tabular}{|c|c|c|c|c|c|}
\hline $\begin{array}{l}\text { Hibrid } \\
\text { (1) }\end{array}$ & $\begin{array}{l}\text { Mútrágya-kezelés } \\
\text { (2) }\end{array}$ & $\begin{array}{c}\text { Fehérje } \\
\% \\
(3)\end{array}$ & $\begin{array}{c}\text { Keményítô } \\
\% \\
(4) \\
\end{array}$ & $\begin{array}{c}\text { Olaj } \\
\% \\
(5) \\
\end{array}$ & $\begin{array}{c}\text { Szárazanyag } \\
\% \\
(6) \\
\end{array}$ \\
\hline \multirow{3}{*}{$\begin{array}{l}\text { PR38 } \\
\text { B12 }\end{array}$} & N120 P80 K0 & 9,52 & 68,51 & 4,94 & 88,46 \\
\hline & N120 P80 KCl 200 & 9,47 & 71,19 & 5,02 & 89,28 \\
\hline & N120 P80 Kamex 200 & 9,93 & 65,30 & 4,97 & 88,46 \\
\hline Átlag (7) & & 9,64 & 68,33 & 4,97 & 88,73 \\
\hline \multirow{3}{*}{$\begin{array}{l}\text { PR37 } \\
\text { D25 }\end{array}$} & N120 P80 K0 & 9,21 & 68,95 & 4,51 & 89,24 \\
\hline & N120 P80 KCl 200 & 9,38 & 69,73 & 4,37 & 89,52 \\
\hline & N120 P80 Kamex 200 & 9,29 & 70,57 & 4,38 & 88,53 \\
\hline Átlag (7) & & 9,29 & 69,75 & 4,42 & 89,10 \\
\hline \multirow{3}{*}{$\begin{array}{l}\text { KWS } \\
353\end{array}$} & N120 P80 K0 & 10,42 & 68,11 & 4,73 & 88,61 \\
\hline & N120 P80 KCl 200 & 10,53 & 69,00 & 4,86 & 87,72 \\
\hline & N120 P80 Kamex 200 & 10,51 & 68,45 & 4,37 & 89,08 \\
\hline Átlag (7) & & 10,48 & 68,52 & 4,65 & 88,47 \\
\hline \multirow{3}{*}{$\begin{array}{l}\text { DKC } \\
5211\end{array}$} & N120 P80 K0 & 9,91 & 68,98 & 4,58 & 88,81 \\
\hline & N120 P80 KCl 200 & 9,90 & 69,26 & 4,68 & 88,98 \\
\hline & N120 P80 Kamex 200 & 9,56 & 69,23 & 4,84 & 89,13 \\
\hline Átlag (7) & & 9,79 & 69,16 & 4,70 & 88,97 \\
\hline \multirow{3}{*}{$\begin{array}{l}\text { PR36 } \\
\text { K67 }\end{array}$} & N120 P80 K0 & 9,05 & 68,69 & 5,35 & 87,70 \\
\hline & N120 P80 KCl 200 & 8,93 & 72,04 & 4,90 & 88,97 \\
\hline & N120 P80 Kamex 200 & 9,11 & 68,75 & 4,88 & 87,88 \\
\hline Átlag (7) & & 9,03 & 69,83 & 5,04 & 88,18 \\
\hline
\end{tabular}

Table 5. The effect of potassium fertilisation on the quality of maize hybrids (Hajdúböszörmény 2008). (1) Hybrid, (2) Fertiliser treatment, (3) Protein \%, (4) Starch \%, (5) Oil \%, (6) Dry matter \%, (7) Average.

Kálium mútrágyázás nélkül az általunk vizsgált hibridek mindegyikénél a keményítôtartalom csökkent.

Kísérletünkben a fehérje százalék hibridtôl és az NPK trágyakezeléstól függốen 8,93-10,53\% között változott, ami magas fehérjetartalomnak számít. Egyértelmúen megállapítható, hogy az intervallumon belül is általában az $\mathrm{N}$ 
$120, \mathrm{P}_{2} \mathrm{O}_{5} 80, \mathrm{~K}_{2} \mathrm{O} 200(\mathrm{KCl}) \mathrm{kg} /$ ha hatóanyag kezelésnél volt legmagasabb a fehérje százalék. Egyedüli kivétel a PR36K67 hibrid volt, amely ennél a kezelésnél érte el a legalacsonyabb - 8,93 \% - fehérjetartalmat. A legnagyobb fehérje \%-ot ebben az évben is a KWS 353 hibrid mintáiban mértük (10,42-10,53\%). A kontroll (K nélküli) kezelésnél kaptuk az alacsonyabb (10,42\%) fehérjetartalmakat.

A legkisebb fehérje százalékot - a kezelések átlagában - a PR36K67 hibridnél mértünk 9,03\%-ot.

Az olaj százalék hibridtől és kezeléstől függően 4,37-5,35\% között változott.

A kísérleti eredményeink alapján azt tapasztaltuk, hogy a hibridek keményítőtartalma mellett döntô tényezô a termőképesség, ha az kiváló, akkor területegységről több keményítôt lehet lehozni, megfelelő kierjeszthetôség esetén pedig több bioetanolt.

A 2008. évben a kukoricahibridek etanol hozama az alábbi volt: 1. PR36K67: 6500 1/ha; 2. PR37D25: 5700 1/ha; 3. PR38B12: 5600 1/ha; 4. DKC 5211: 4200 1/ha; 5. KWS 353: 4000 1/ha (6. ábra).

\section{6. ábra. A kukoricahibridek hektáronkénti etanol hozama}

(Hajdúböszörmény 2008)

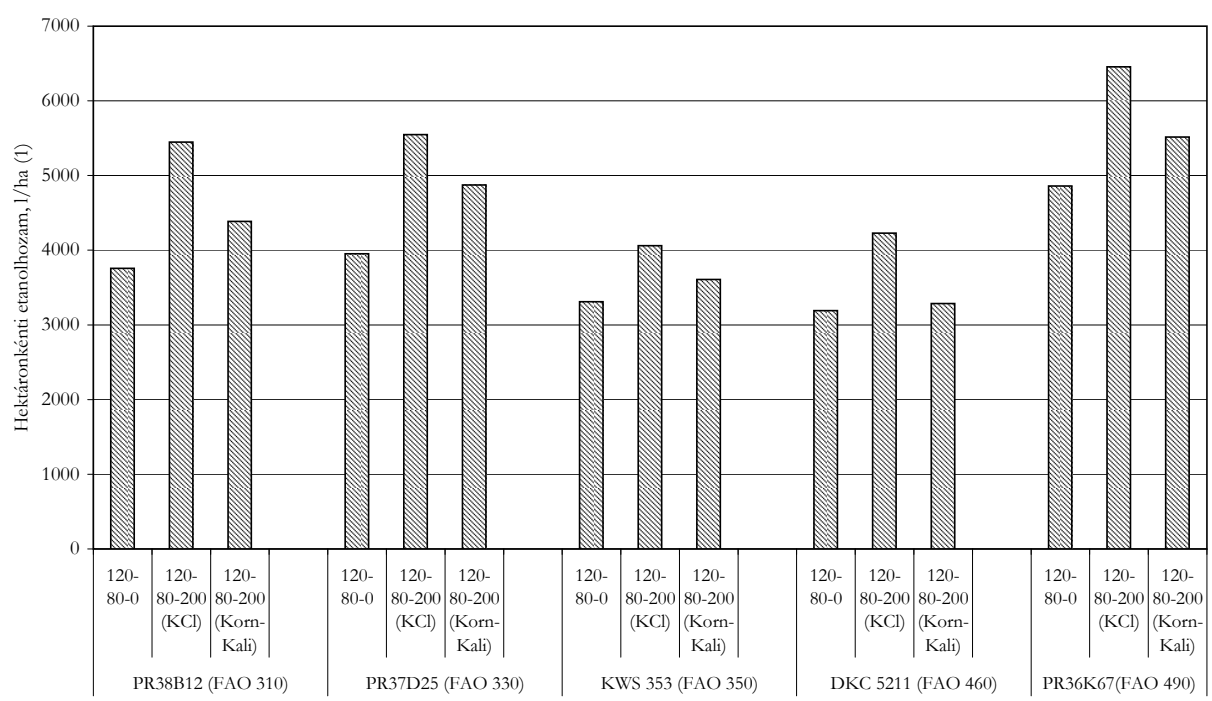

Figure 6. Maize hybrids' etanol yield per hectare (Hajdúböszörmény 2008). (1) Ethanol yield per hectare, 1 ha $^{-1}$. 
A bioetanol kihozatalban rendkívüli nagy különbségeket (4000-6500 1/ha) a hibridek eltérô termőképessége, ill. termése eredményezte.

\section{Következtetések}

Kísérletünkben a kálium mútrágyázás hatását vizsgáltuk a termésre és a keményítô százalék változására, egységes $\mathrm{N} 120, \mathrm{P}_{2} \mathrm{O}_{5} 80 \mathrm{~kg} /$ ha ellátás mellett.

A jövőben a minôséget a termesztési cél alapján kell megítélnünk és értékelnünk. Takarmányozási cél esetén kedvező lehet a magasabb fehérjetartalom, bioetanol előállítás szempontjából viszont ez mellékes, sốt kedvezôbb, ha alacsonyabb.

Megállapítható, hogy a világon a zöldenergiák, a bioetanol, biodízel előállítás nagy lendületet vett, hiszen belátható idôn belül a fosszilis energiák (kôolaj, földgáz, szén stb.) ki fognak merülni. Azonban a fosszilis energiák helyettesítése vagy kiváltása bioetanollal csak korlátozott lehet, hiszen azt alapvetó élelmiszernövényekből állítják elő. Például Brazíliában cukornádból, az USA-ban, Franciaországban és hazánkban is fóleg kukoricából.

\section{IRODALOM}

Berzsenyi Z.-Varga K.: 1986. A kukoricahibridek optimális tőszámát és N- mútrágya reakcióját meghatározó tényezók vizsgálata tartamkísérletben. Georgikon Napok. Keszthely. PATE Kiadvány. 36-42.

Breteler, H.: 1976. Nitrogéntrágyázás hatása a magas lizintartalmú kukoricafajták hozamára és fehérje-összetételére. Agric. London 27. 10: 978-982.

Decan, J.-Pujol, B.: 1974. Az öntözés és a nitrogéntrágyázás által a különféle kukorica fajták termésének mennyiségére és minőségére gyakorolt hatások összehasonlító vizsgálata. Anuls. Argon. Paris. 25. 1: 93-110.

Getmanec, A.J.-Kaljavzo, Sz. P.: 1981. Vlijnie minerel'nüh udobrenij na kacsesztvo Zerna Kukuruzü. Agrohimija. Moszkva. 2: 146-153.

Gundel, J.-Babinszky, L.-Kemenes, M.: 1981. A silózással tartósított szemes kukorica takarmányértéke hízó sertések részére. Állattenyésztés és takarmányozás. Budapest. 30. 2: 107-115.

Gyốrffy B.: 1976. A kukorica termésére ható növénytermesztési tényezôk értékelése. Agrártudományi Közlemények. 35: 239-266.

Györffy B.-I’só I.-Bölöni I.: 1965. Kukoricatermesztés. Mezógazdasági Kiadó. Budapest. 411.

Izsáki Z.: 2006. A kukorica minőségorientált tápanyag-ellátása. Szántóföld. 10. 1: 7-12.

Kiss I.-né.: 1982. A fajtakérdés modern értelmezése. IKR. Bábolna. 
Nagy J.: 1995. A mútrágyázás hatásának értékelése a kukorica (Zea mays L.) termésére eltérố évjáratokban. Növénytermelés. 44. 4: 493-506.

Nagy J.: 1997. A mútrágyázás hatása a kukorica (Zea mays L.) termésére öntözés nélküli és öntözéses termesztésben. Agrokémia és Talajtan. 46. 1-4: 275-288.

Pásztor, K.-Kováts, A.: 1985. Changes in the production of maize hybrids due to mutant parent lines. Acta relationship of hibrid maize. The Madras Agricultural Journal. New Delhi. 60. 8: 684-690.

Pekáry K.: 1969. N-P-K- Mútrágya adagolási kísérletek kukoricával két északkelet-magyarországi termőhelyen [In: I'só I. (szerk.) Kukoricatermesztési kísérletek 1965-1968.] Akadémiai Kiadó. Budapest. 186-201.

PoppJ.-Potori N.: 2006. Agrárgazdasági Kutató Intézet. Budapest. 11: 10.

Prokszáné P. Zs.-Harmati I.: 1988. A kukorica hibridek keményítō-, fehérje- és olajtartalma. Növénytermelés. 37. 1: 17-26.

Prokszáné P. Zs.-Széll E.-Kovácsné K. M.: 1995. A nitrogén mútrágyázás hatása a kukorica (Zea mays L.) termésére és néhány beltartalmi mutatójára eltérố évjáratokban réti öntés talajon. Növénytermelés. 44. 1: 33-42.

Sárvári M.-Szabó P.: 1998. A termesztési tényezők hatása a kukorica termésére. Növénytermelés. 47. 2: 213-221.

Sárvári M.-Boros B.: 2009. Ipari célú kukoricatermesztés. Agro Napló. 13. 5: 33-34.

Veress I.: 1973. A kukoricaszem aminosavjainak változása nitrogénmútrágyázás hatására. Növénytermelés. 22. 2: 125-135.

A szerzôk levelezési címe - Address of the authors:

Boros Beáta-Dr. Sárvári Mihály

Debreceni Egyetem AGTC

Növénytudományi Intézet

Debrecen

Böszörményi út 138.

H-4032 